\title{
30. OXYGEN-ISOTOPE COMPOSITION OF CHERT FROM THE MID-PACIFIC MOUNTAINS AND HESS RISE, DEEP SEA DRILLING PROJECT LEG $62^{1}$
}

\author{
James R. Hein, U.S. Geological Survey, 345 Middlefield Road, Menlo Park, California \\ and \\ Hsueh-Wen Yeh, Hawaii Institute of Geophysics, University of Hawaii, Honolulu, Hawaii
}

\begin{abstract}
We measured oxygen-isotope compositions of 16 siliceous rocks from Deep Sea Drilling Project Sites 463, 464, 465, and 466 (Leg 62). Samples are from deposits that range in age from about 40 to 103 m.y. and that occur at sub-bottom depths of 9 to 461 meters. Mean $\delta^{18} \mathrm{O}$ values range from 28.4 to $36.8 \%$ and $36.0 \pm 0.3 \%$ for quartz-rich and opal-CTrich rocks, respectively. $\delta^{18} \mathrm{O}$ values in chert decrease with increasing sub-bottom depth; the slope of the $\delta^{18} \mathrm{O} / \mathrm{depth}$ curve is less steep for Site 464 than for the other sites which indicates that chert at Site 464 formed at higher temperatures than chert at Sites 463,465 , and 466 . Temperatures of formation of cherts were 7 to $42^{\circ} \mathrm{C}$, using the silica-water fractionation factor of Knauth and Epstein (1976), or 19 to $56^{\circ} \mathrm{C}$, using the equation of Clayton et al. (1972). Temperatures in the sediment where the cherts now occur are lower than their isotopically determined temperatures of formation, which means that the cherts record an earlier history when temperatures in the sediment section were greater. Estimated sediment temperatures when the cherts formed are comparable to, but generally slightly lower than, those calculated from Knauth and Epstein's equation. The isotopic composition of cherts is more closely related to environment of formation (diagenetic environment) or paleogeothermal gradients, than to paleoclimates (bottom-water temperatures). Opal-CT-rich rocks may better record paleo-bottom-water temperature.

In Leg 62 cherts, better crystallinity of quartz corresponds to lower $\delta^{18} \mathrm{O}$ values; this implies progressively higher temperatures of equilibration between quartz and water during maturation of quartz. The interrelationship of $\delta^{18} \mathrm{O}$ and crystallinity is noted also in continental-margin deposits such as the Monterey Formation-but for higher temperatures. The apparent temperature difference between open-ocean and continental-margin deposits can be explained by the dominant control of temperature on silica transformation in the rapidly deposited continental-margin deposits, whereas time, as well as temperature, has a strong influence on the transformations in open-ocean deposits.

Comparisons between the chemistry and $\delta^{18} \mathrm{O}$ values of cherts reveal two apparent trends: both boron and $\mathrm{SiO}_{2}$ increase as $\delta^{18} \mathrm{O}$ increases. However, the correspondence between $\mathrm{SiO}_{2}$ and $\delta^{18} \mathrm{O}$ is only apparent, because the two cherts lowest in $\mathrm{SiO}_{2}$ are also the most deeply buried, so the trend actually reflects depth of burial. The correspondence between boron and $\delta^{18} \mathrm{O}$ supports the conclusion that boron is incorporated in the quartz crystal structure during precipitation.
\end{abstract}

\section{INTRODUCTION}

We determined the oxygen-isotope compositions of 16 siliceous rocks cored during DSDP Leg 62 (Fig. 1). The analyzed rocks include 13 cherts and jaspers, one siliceous chalk, one quartz porcellanite, and one porcellanite containing quartz and opal-CT (Table 1). We discuss the isotopic compositions in relation to temperatures of formation and the chemical and mineralogical compositions of the cherts. Temperatures of formation were determined both with the empirically derived fractionation factor of Knauth and Epstein (1976), and with the experimentally derived $\mathrm{SiO}_{2}$-water fractionation factor of Clayton et al. (1972). The 16 siliceous rocks discussed here are a subset of the 65 siliceous rocks described by Hein et al. (this volume), who give detailed descriptions and chemical analyses of the rocks.

Samples analyzed for their oxygen-isotope compositions are from chalk and limestone at Sites 463, 465, and 466 and from pelagic clay and marlstone at Site 464 . The distributions of the analyzed siliceous rocks with respect to lithologies and time are displayed in Figure 2. At Site 463, 822.5 meters of Quaternary through upper

\footnotetext{
${ }^{1}$ Initial Reports of the Deep Sea Drilling Project, Volume 62.
}

Barremian nannofossil ooze, chalk, and limestone with minor amounts of chert and volcanic ash were drilled. At Site 464, 308.5 meters of Quaternary to Upper Miocene siliceous clay, lower Miocene to Upper Cretaceous brown clay, Cenomanian to upper Aptian chert and nannofossil limestone, and highly altered tholeiitic basalt were drilled. At Site 465 (Holes 465 and 465A), on Southern Hess Rise, 476 meters of Quaternary through upper Albian calcareous ooze, limestone, minor chert, and highly altered trachyte were drilled. At Site 466, also on southern Hess Rise, 312 meters of Quaternary to upper Albian calcareous sediments with minor chert and pyritic clay were drilled.

\section{METHODS}

The fluorination method of Taylor and Epstein (1962) was used to extract oxygen from the siliceous rocks for determination of ${ }^{18} \mathrm{O} /{ }^{16} \mathrm{O}$ ratios. Samples were quantitatively converted to $\mathrm{CO}_{2}$ and isotopically analyzed with a dual-collector mass spectrometer. Results are reported as $\delta^{18} \mathrm{O}_{\mathrm{SMO}}$ values that are the per mill deviation of the ${ }^{18} \mathrm{O} /{ }^{16} \mathrm{O}$ ratio of a sample from that of standard mean ocean water (SMOW) (Craig, 1961). Two (and in one case three) extractions and ${ }^{18} \mathrm{O} /{ }^{16} \mathrm{O}$ determinations were made on each sample. The mean $\delta^{18} \mathrm{O}_{\text {SMOw }}$ values, replicate run values, and the deviations from means are reported in Table 1.

Siliceous rocks were pretreated before isotopic analysis: (1) carbonate minerals were removed with dilute $10 \% \mathrm{HCl}$ (by volume); the 


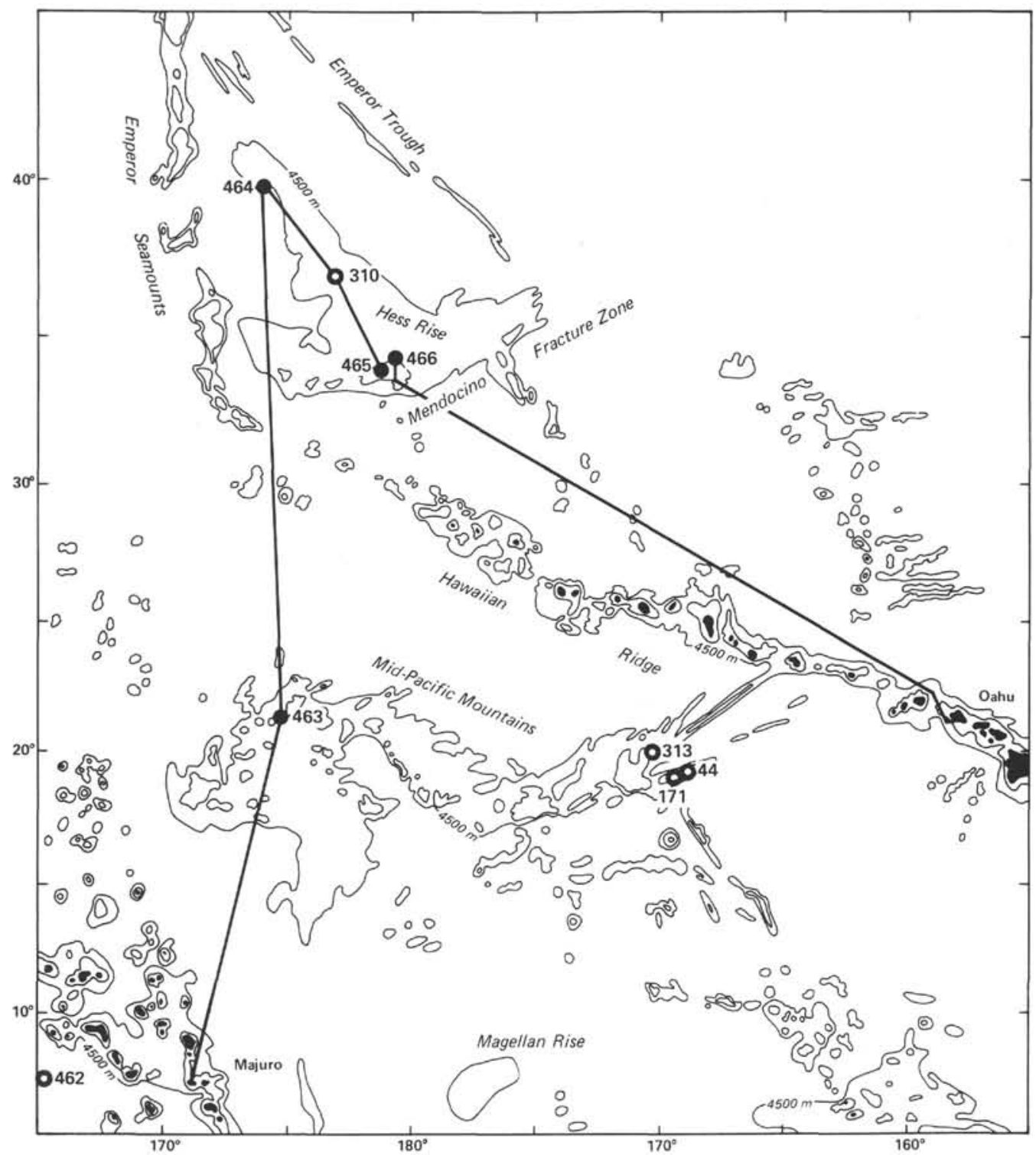

Figure 1. Location of Sites $463,464,465$, and 466 ( $\operatorname{Leg} 62$ ), and other DSDP Sites. Solid circles are locations of measurements of thermal conductivities and heat flows used in Table 2 (Jessop et al., 1976).

treatment was carried out at room temperature and has no effect on the $\delta^{18} \mathrm{O}_{\text {SMOw }}$ of the chert (Yeh and Epstein, in prep.); (2) the absorbed and other loosely bound waters were removed from the chert prior to fluorination, by heating the samples at about $250^{\circ} \mathrm{C}$ under high vacuum. After dehydration, samples were loaded into $\mathrm{Ni}$ reaction vessels under zero-humidity atmosphere.

Coexisting opal-CT and quartz were not separated before isotopic analysis. Values of $\delta^{18} \mathrm{O}$ for these samples (Table 1) are probably higher than they would be if the quartz were isolated and analyzed separately, if Knauth and Epstein's (1975) and Pisciotto's (1978) observations are applicable to our samples. Major, minor, and trace elements of the cherts analyzed for their oxygen-isotope compositions are presented by Hein et al. (this volume).

\section{ANALYTICAL RESULTS}

Analyzed cherts are from deposits that range in age from about 40 to $103 \mathrm{~m}$.y. and that occur at sub-bottom depths of 9 to 461 meters. Mean $\delta^{18} \mathrm{O}$ values range from
28.4 to $36.8 \%$ for quartz-rich samples, and 36.0 and $36.3 \%$ for the two opal-CT-rich rocks. These values fall within the range of 27.1 to $41.8 \%$ reported for other marine cherts and porcellanites (Knauth and Epstein, 1975; Levitan et al., 1975; Kolodny and Epstein, 1976; Kastner, 1976). The average of mean $\delta^{18} \mathrm{O}$ values and maximum and minimum $\delta^{18} \mathrm{O}$ values become progressively higher from Site 464, on northern Hess Rise, to Site 463 , in the Mid-Pacific Mountains, to Sites 465 and 466 , on southern Hess Rise.

$\delta^{18} \mathrm{O}$ values of cherts show well-defined decreases with increasing depth of occurrence at Sites 463, 464, and 465 , if values for opal-CT-rich rocks are excluded (Fig. 3). We are not sure why $\delta^{18} \mathrm{O}$ values for Site 466 cherts do not define a straight line (Fig. 3), but two possibilities are: (1) if Sample 466-9-1, $64 \mathrm{~cm}$ contains much organic C, analytical precision would be poor; or (2) if 
Table 1. $\delta^{18}$ OSMOW values of DSDP Leg 62 cherts.

\begin{tabular}{|c|c|c|c|c|c|c|c|c|}
\hline \multirow[b]{2}{*}{ Sample } & \multirow[b]{2}{*}{ Lithology } & \multicolumn{4}{|c|}{ Mineralogy } & \multirow{2}{*}{$\begin{array}{c}\delta^{18} \text { OSMOW } \\
\text { (replicate runs) }\end{array}$} & \multirow{2}{*}{$\underset{\text { (mean) }}{\delta^{18} \text { OSMOW }}$} & \multirow{2}{*}{$\begin{array}{l}\text { Deviation from } \\
\text { the Mean }\end{array}$} \\
\hline & & Major & Moderate & Minor & Trace & & & \\
\hline $463-6-6,36 \mathrm{~cm}$ & Tan chert & Quartz & & Calcite & & $\begin{array}{l}35.5 \\
36.0\end{array}$ & 35.8 & 0.25 \\
\hline $463-10-6,82 \mathrm{~cm}$ & Siliceous chalk & Calcite & Opal-CT & Quartz & Smectite & $\begin{array}{l}35.7 \\
36.2\end{array}$ & 36.0 & 0.25 \\
\hline $463-22, \mathrm{CC}(\mathrm{A})$ & Brown chert & Quartz & & & Smectite & $\begin{array}{l}32.7 \\
33.4\end{array}$ & 33.1 & 0.35 \\
\hline $463-52, \mathrm{CC}$ & Calcareous gray chert & $\begin{array}{l}\text { Quartz } \\
\text { Calcite }\end{array}$ & & & Smectite & $\begin{array}{l}28.0 \\
28.8\end{array}$ & 28.4 & 0.40 \\
\hline $464-10-3,70 \mathrm{~cm}$ & White chert & Quartz & & Opal-CT & & $\begin{array}{l}35.6 \\
35.7\end{array}$ & 35.7 & 0.05 \\
\hline $464-10-4,34 \mathrm{~cm}$ (A) & Brown chert & Quartz & & & $\begin{array}{l}\text { Smectite, } \\
\text { calcite }\end{array}$ & $\begin{array}{l}33.8 \\
34.1\end{array}$ & 34.0 & 0.15 \\
\hline $464-11-1,41 \mathrm{~cm}$ & Orange jasper & Quartz & & & Opal-CT & $\begin{array}{l}32.9 \\
32.9\end{array}$ & 32.9 & 0.00 \\
\hline $464-14-1,40 \mathrm{~cm}$ & Black chert & Quartz & & & $\begin{array}{l}\text { Smectite, } \\
\text { Pyrite }\end{array}$ & $\begin{array}{l}33.1 \\
33.2\end{array}$ & 33.2 & 0.05 \\
\hline $464-17, C C$ & Red-brown jasper & Quartz & & Calcite & Smectite & $\begin{array}{l}27.8 \\
30.2 \\
28.7\end{array}$ & 28.9 & 1.20 \\
\hline $465-2, \mathrm{CC}(\mathrm{A})$ & Gray transparent chert & Quartz & & & & $\begin{array}{l}36.3 \\
37.0\end{array}$ & 36.7 & 0.35 \\
\hline $465-2, \mathrm{CC}(\mathrm{B})$ & Quartz porcellanite & Quartz & & Apatite & & $\begin{array}{l}36.8 \\
36.7\end{array}$ & 36.8 & 0.05 \\
\hline $465 \mathrm{~A}-40-1,26 \mathrm{~cm}$ & Tuffaceous black chert & Quartz & & & & $\begin{array}{l}29.9 \\
30.1\end{array}$ & 30.0 & 0.10 \\
\hline $466-9-1,64 \mathrm{~cm}$ & Gray chert & Quartz & & Barite & $\begin{array}{l}\text { Gypsum, } \\
\text { smectite }\end{array}$ & $\begin{array}{l}33.8 \\
34.0\end{array}$ & 33.9 & 0.10 \\
\hline $466-15-5,45 \mathrm{~cm}$ & Brown jasper & Quartz & & Barite & Smectite & 34.9 & 35.3 & 0.40 \\
\hline $466-27, \mathrm{CC}(\mathrm{A})$ & $\begin{array}{l}\text { Quartz, opal-CT, } \\
\text { porcellanite }\end{array}$ & Opal-CT & Quartz & & Barite & $\begin{array}{l}35.9 \\
36.7\end{array}$ & 36.3 & 0.40 \\
\hline $466-34-1,8 \mathrm{~cm}(\mathrm{~A})$ & Blue-gray chert & Quartz & & & & $\begin{array}{l}32.8 \\
33.0\end{array}$ & 32.9 & 0.10 \\
\hline
\end{tabular}

Note: Calcite was removed from all samples before isotopic analysis.

the Pliocene-Eocene or Eocene-Maastrichtian unconformities at Site 466 (Fig. 2) are erosional rather than simply nondepositional, cherts from 466-9-1, $64 \mathrm{~cm}$ and $466-15-5,45 \mathrm{~cm}$ could have formed at significantly different depths of burial than their present stratigraphic positions indicate. The $\delta^{18} \mathrm{O} /$ depth curve for Site 464 , on northern Hess Rise, has a markedly less steep slope than do the curves for the other sites.

$\delta^{18} \mathrm{O}$ values of cherts show distinct variations with age of the enclosing sediment (Fig. 4). The few data available from Leg 62 samples show that $\delta^{18} \mathrm{O}$ is increased about $3 \%$ for cherts in sediment deposited 80 to 90 m.y. ago, then is decreased $4 \%$ in sediment deposited back to about $115 \mathrm{~m} . \mathrm{y}$. ago, where $\delta^{18} \mathrm{O}$ remains constant at about $33 \%$ back to 135 m.y. ago. Additional analyses may change this pattern significantly. Because chert does not form until 40 m.y. after deposition of the host sediment (Hein et al., this volume), the Cretaceous times just listed should be translated $40 \mathrm{~m}$.y. toward the present to place the $\delta^{18} \mathrm{O}$ changes into a more meaningful temporal scheme (see section on temperature of formation).

\section{$\delta^{18} \mathrm{O}$ and Silica Phases}

No trend is evident in the $\delta^{18} \mathrm{O}$ values of the three samples that contain more than a trace of opal-CT (Table 1). However, all three samples do fall within a narrow $\delta^{18} \mathrm{O}$ range of $36.0 \pm 0.3 \%$. In contrast, there is a parallel trend of $\delta^{18} \mathrm{O}$ values and crystallinity of quartz (Fig. 5). Quartz crystallinity was measured according to the technique of Murata and Norman (1976) and is based on a scale of 10 , plutonic quartz (high crystallinity) defining the high end, and diagenetic quartz (poor crystallinity) defining the low end. For Leg 62 cherts, better crystallinity of quartz corresponds to lower $\delta^{18} \mathrm{O}$ values, implying higher temperatures of equilibration between quartz and water during formation of bettercrystallized quartz. The sample with the best crystallinity, 463-52,CC (Fig. 5), was also the most deeply buried (Table 2).

\section{$\delta^{18} \mathrm{O}$ and Chemical Composition of Chert}

In general, the cherts are chemically very pure, averaging $96.17 \% \mathrm{SiO}_{2}(\sigma=0.92)$ and $2.91 \%$ loss of fusion $(\sigma=0.66)$; that is, $\mathrm{SiO}_{2}$ and volatiles exceed $99 \%$ (Hein et al., this volume). Of the cherts analyzed for their oxygen-isotope compositions, only that from $465 \mathrm{~A}-40-1,26 \mathrm{~cm}$ contains significant non-carbonate contamination $\left(7.57 \% \quad \mathrm{Al}_{2} \mathrm{O}_{3}\right)$. Comparisons between the chemistry (Hein et al., this volume) and the $\delta^{18} \mathrm{O}$ values of cherts reveal two apparent trends: both $\mathrm{SiO}_{2}$ and boron increase as $\delta^{18} \mathrm{O}$ increases (Figs. 6 and 7). However, the correspondence of $\mathrm{SiO}_{2}$ to $\delta^{18} \mathrm{O}$ is only apparent, because the two cherts with the lowest $\mathrm{SiO}_{2}$ concentrations (a calcareous and a tuffaceous chert; Table 1) are also the most deeply buried cherts (Fig. 6), so this trend actually reflects depth of burial. The trend between boron and $\delta^{18} \mathrm{O}$ supports the conclusion that boron was incorporated in the quartz crystal structure during precipitation (Hein et al., this volume). No other trends are seen between $\delta^{18} \mathrm{O}$ values and other elements analyzed. Especially noteworthy is the lack of correspondence between $\delta^{18} \mathrm{O}$ and $\mathrm{Al}_{2} \mathrm{O}_{3}$ or $\mathrm{CaO}$, suggesting that possible contamination by terrigenous, volcanic, and calcareous debris in the cherts has not significantly affected the isotopic values. 

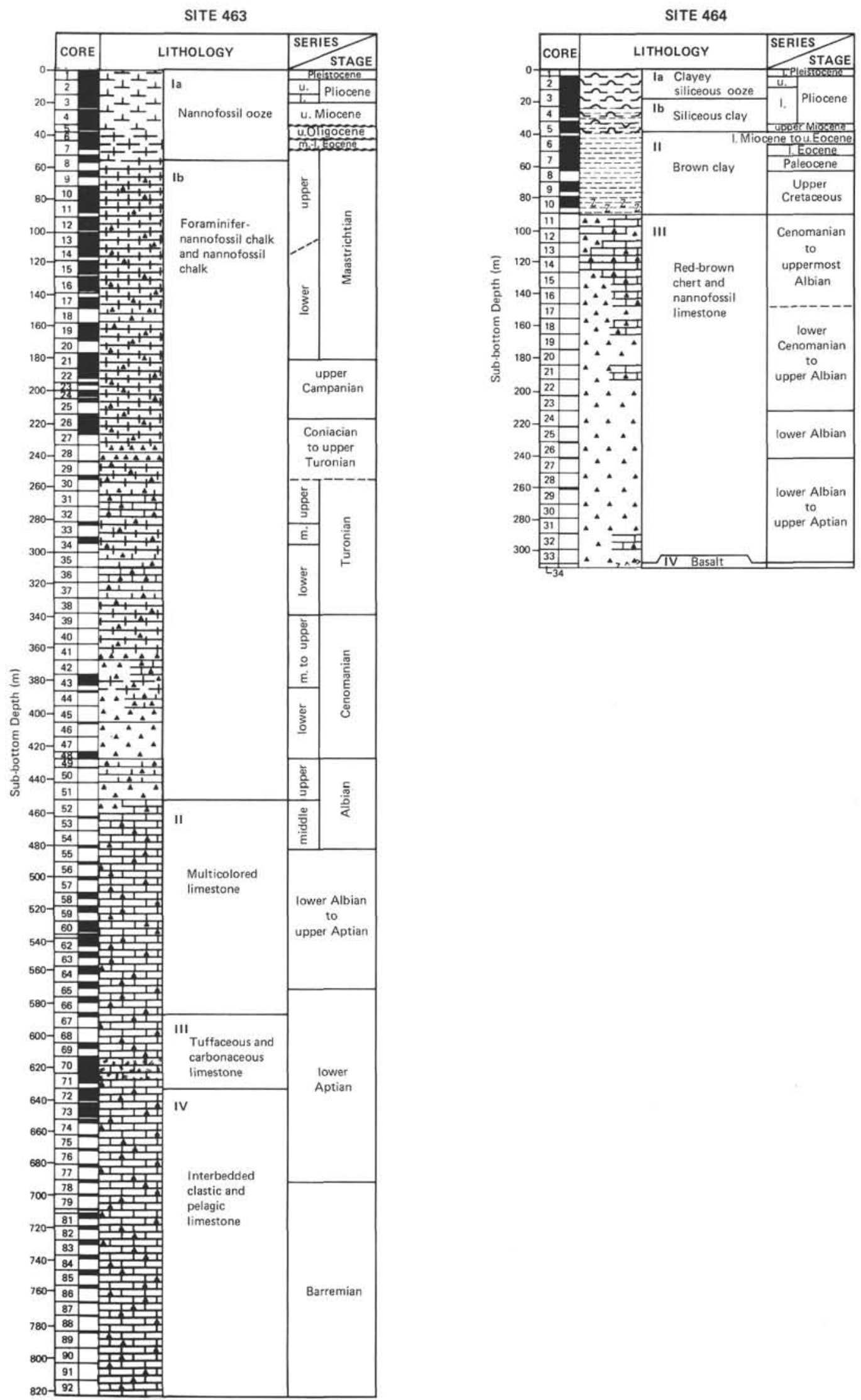

Figure 2. General lithologies, ages, and stratigraphic locations of cherts analyzed for oxygen-isotope compositions. See Tables 1 and 2 and Hein et al. (this volume) for descriptions of each studied rock. 


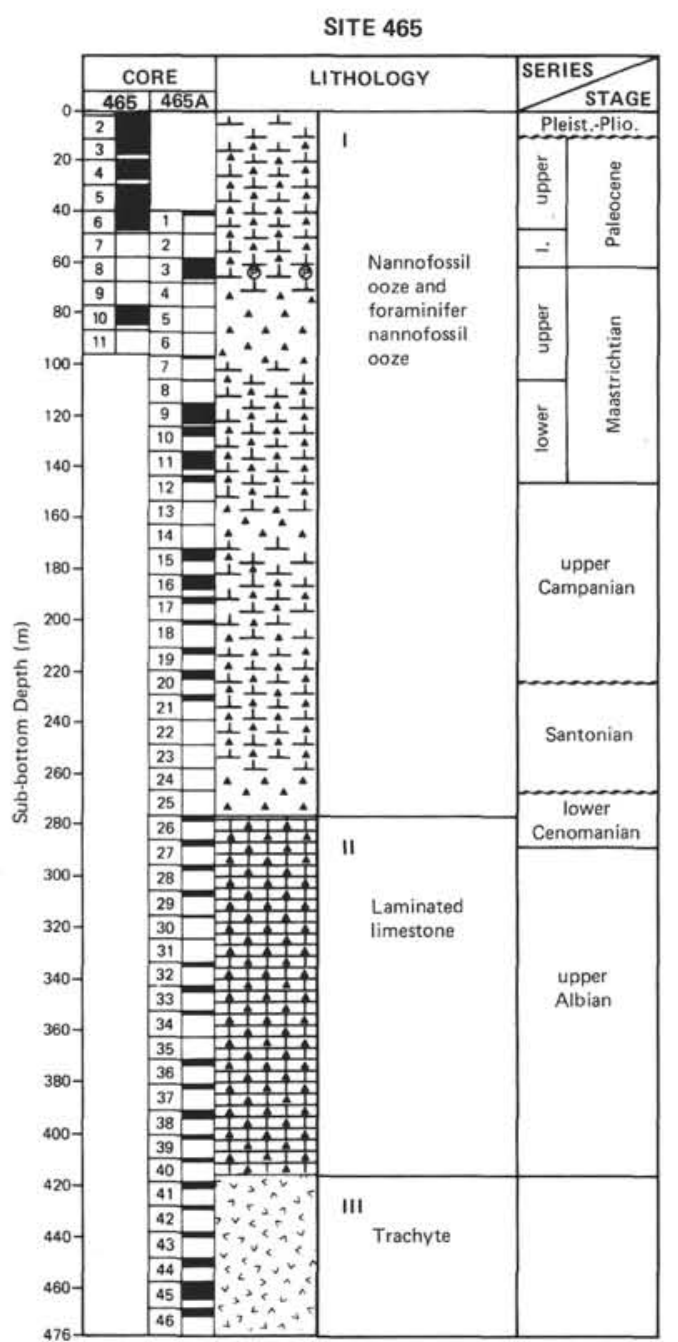

Figure 2. (Continued).

\section{TEMPERATURE OF FORMATION}

Temperatures of formation of cherts collected during Leg 62 were calculated from the equations of Knauth and Epstein (1976) and Clayton et al. (1972), assuming $0.0 \%$ o for the waters of formation. The $\delta^{18} \mathrm{O}$ value of pre-Pleistocene deep marine water has been suggested to be about $-1.0 \%$, which, if correct, would lower the isotopically derived temperatures by about $3^{\circ} \mathrm{C}$ (Table 2; Savin, 1977). Knauth and Epstein's quartz/water fractionation factor gives lower temperatures of formation $\left(7-42^{\circ} \mathrm{C}\right)$ than does that of Clayton et al. $\left(19-56^{\circ} \mathrm{C}\right)$ (Table 2; Fig. 8). The temperature in the sediment where the cherts were collected was calculated from estimated geothermal gradients for each site and from the depth of occurrence of each chert (Table 2); temperatures where the cherts occur now are lower than the temperatures of formation of the cherts determined from their oxygenisotope compositions in all but one sample-that containing the most opal-CT. This means either that the cherts record an earlier history when temperatures in the sediments were greater, or that the oxygen-isotope

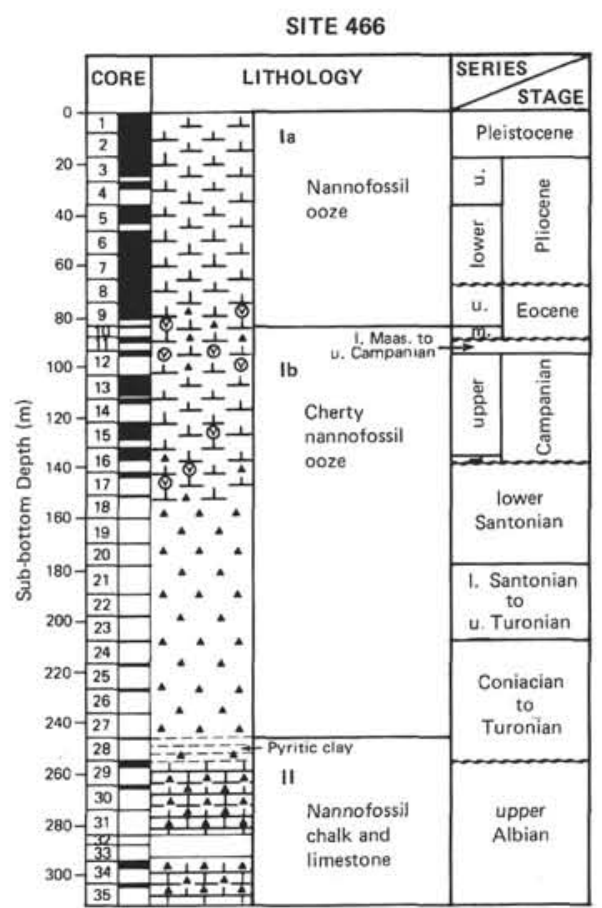

values of the waters of equilibration were significantly different from $0.0 \%$.

We estimated the temperature of formation of each chert by assuming that most chert has formed by about 40 m.y. after the sediment in which it occurs was deposited (Hein et al., this volume), using the Cretaceous bottom-water temperatures of Douglas and Savin (1973), and assuming that Cretaceous geothermal gradients were similar to contemporary ones (Fig. 8). These assumptions produce temperatures of formation comparable with those calculated from Knauth and Epstein's (1976) equation (Fig. 8)-but on the average about $6^{\circ} \mathrm{C}$ lower (about $3.5^{\circ} \mathrm{C}$ if bottom-water had a $\delta^{18} \mathrm{O}$ value of $-1.0 \%$ ). Thus, data from Leg 62 cherts favor the validity of Knauth and Epstein's quartz/water factionation factor for deep-sea cherts.

The greater the amount of opal-CT in a chert, the greater the degree of deviation from our curve of estimated temperature of formation (Fig. 8; points enclosed in rectangles). The sample with minor opal-CT falls on our curve, but those with intermediate to major amounts of opal-CT are displaced toward higher tem- 


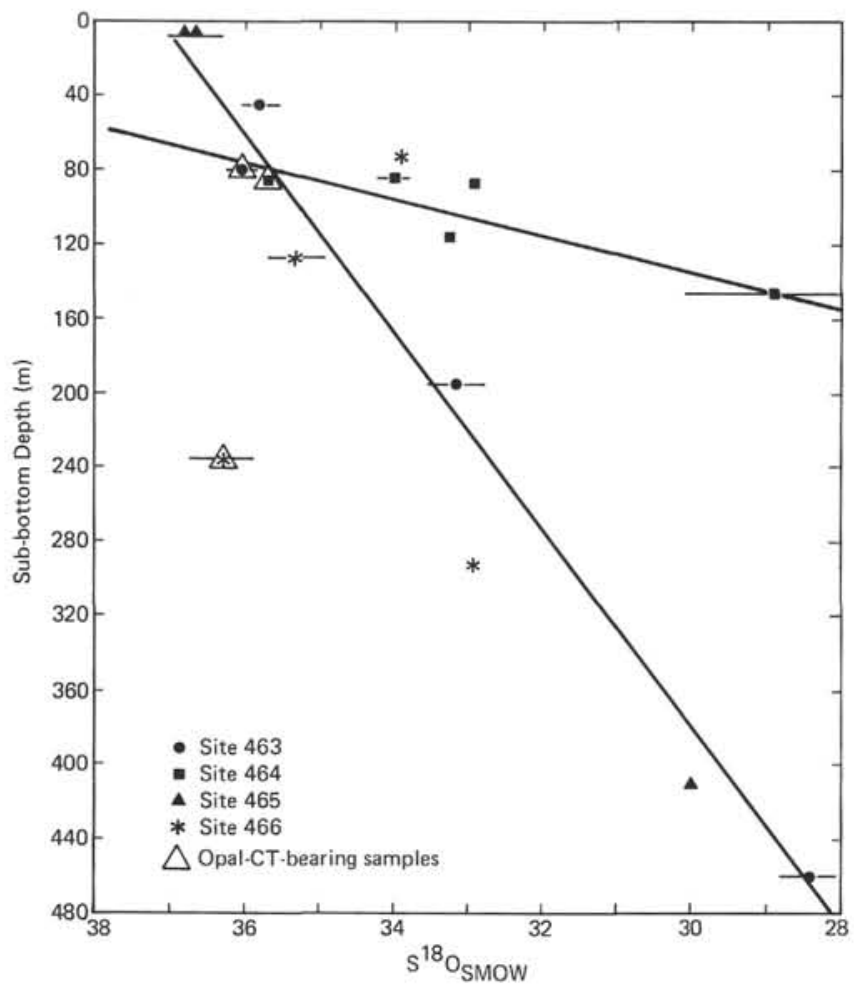

Figure 3. $\delta^{18} \mathrm{O}$ compositions versus sub-bottom depths of Leg 62 cherts. Lines relate samples from the same sites. peratures of formation, one near the curve representing Knauth and Epstein's factor, and the other near the curve representing the factor of Clayton et al. The apparent higher temperatures of formation for opal-CT probably reflects the greater structural-water content in opal-CT; structural water would lower the $\delta^{18} \mathrm{O}$ value for the bulk silica sample.

Two additional observations are apparent from Table 1 and Figure 8: (1) both chert and its quartz-porcellanite rim $(465-2, C C)$ formed at the same temperature, in equilibrium with the same interstitial waters; this suggests either a simultaneous transformation from opal-CT to quartz within both the chert and porcellanite, or rapid quartz precipitation without an opal-CT precursor, the porcellanite reflecting a decrease in the availability of silica; (2) alteration of the trachytic basement rock at Site 465 did not change the isotopic composition of overyling interstitial waters enough to have a noticeable effect on the chert that formed in equilibrium with the interstitial water (see discussion by Lawrence et al., 1975).

\section{DISCUSSION}

Debate continues as to whether $\delta^{18} \mathrm{O}$ values of marine cherts primarily reflect paleoclimates (bottom-water temperatures), or diagenetic environments (Degens and Epstein, 1962; Kolodny and Epstein, 1976; Knauth and Epstein, 1975). Kolodny and Epstein (1976) suggested

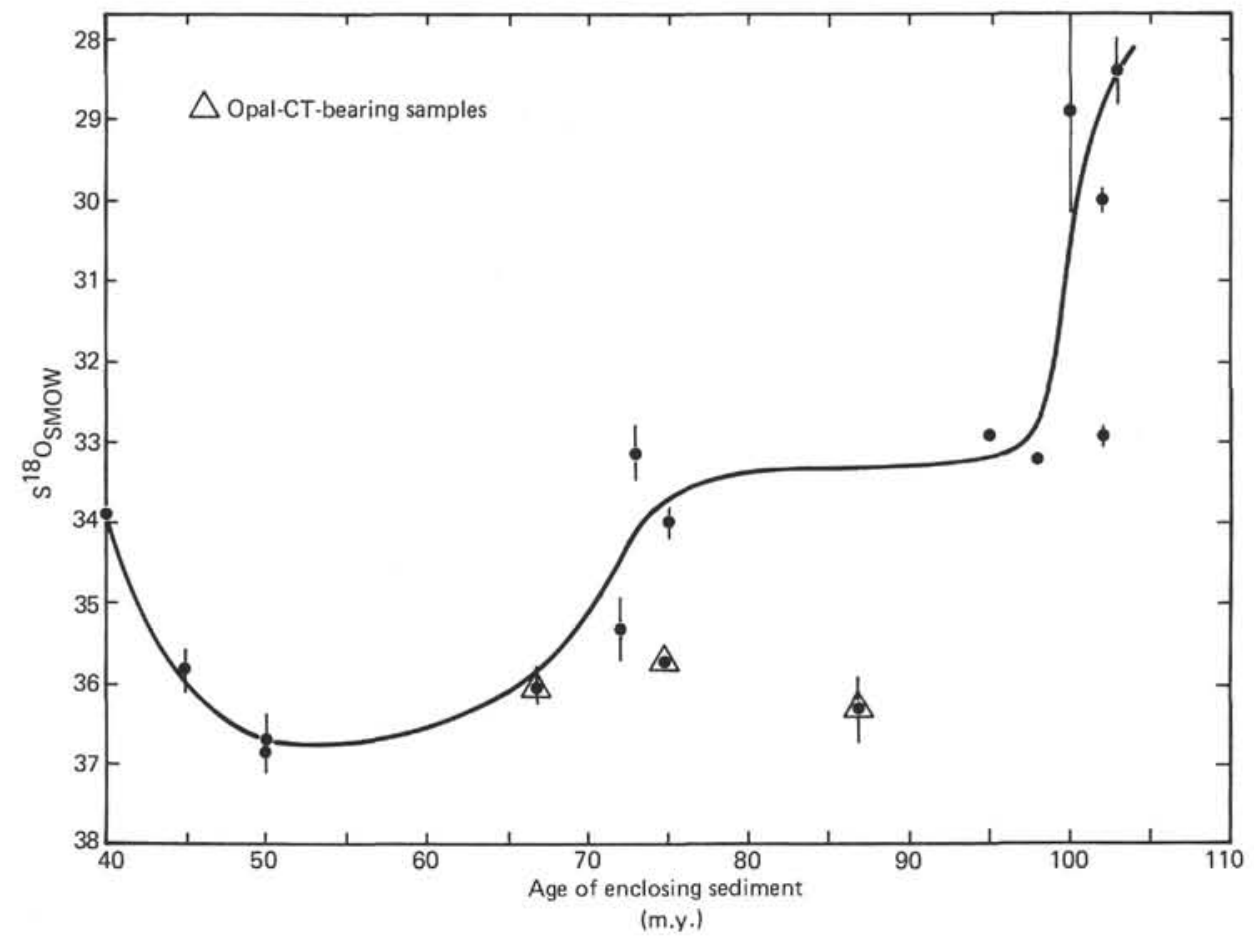

Figure $4 . \delta^{18} \mathrm{O}$ compositions versus age of enclosing sediment of Leg 62 cherts. The triangle above 87 m.y. represents a sample composed mainly of opal-CT, which does not fit the trend of the other samples. 


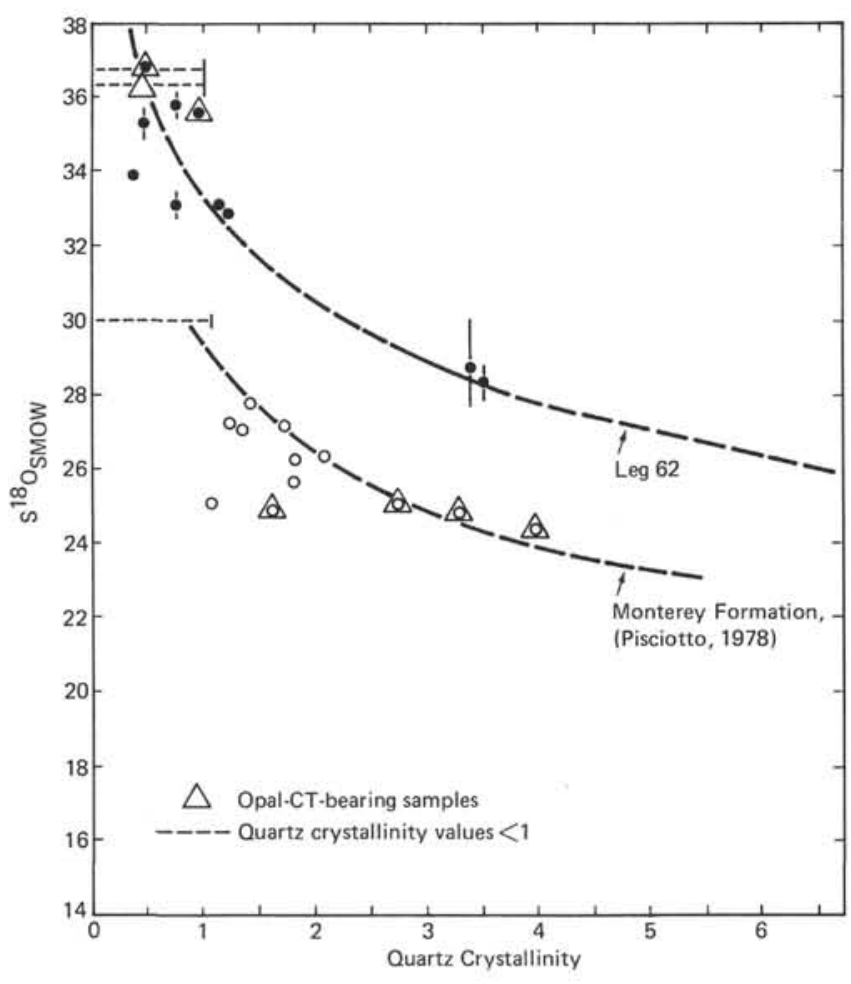

Figure $5 . \delta^{18} \mathrm{O}$ compositions versus the crystallinity of quartz in Leg 62 cherts, and in chert and porcellanite from the Monterey Formation of California. that the isotopic compositions of deep-sea cherts record paleo-bottom-water temperatures (our Fig. 9 shows Leg 62 data plotted on Kolodny and Epstein's fig. 5); they considered that a good match exists between their Tertiary-Cretaceous isotope-temperature curve and the bottom-water-temperature curve of Douglas and Savin (1973).

Data from Leg 62 cherts (ages translated 40 m.y. toward the present) describe a curve representing much greater paleotemperatures, but somewhat similar in the general trend of increasing temperatures with increasing age (Fig. 9); the temperature at which a chert formed depends on both bottom-water temperatures and the geothermal gradients, the higher the bottom-water temperature the greater should be its influence on the sub-bottom-sediment temperature at which the chert formed. Because Cretaceous bottom-water temperatures were much higher than Neogene temperatures, the Cretaceous temperatures derived from cherts should more closely approximate the Cretaceous bottom-watertemperature curve than do the temperatures determined from the Neogene samples, if in fact bottom-water temperature was the dominant control; the opposite effect is observed in Figure 9, suggesting that the isotopic compositions of Leg 62 cherts in large part record diagenetic environments or paleogeothermal gradients.

With the temperatures determined from the equations of Knauth and Epstein (1976), calculated paleo-

Table 2. Temperature and depth of formation of DSDP Leg 62 cherts.

\begin{tabular}{|c|c|c|c|c|c|c|c|c|c|}
\hline Sample & $\begin{array}{l}\text { Sub-bottom } \\
\text { Depth of } \\
\text { Cherts } \\
\text { (m) }\end{array}$ & $\begin{array}{l}\text { Age of } \\
\text { Enclosing } \\
\text { Sediment } \\
\text { (m.y.) }\end{array}$ & $\begin{array}{l}\text { Heat } \\
\text { Flow } \\
\text { (HFU) }\end{array}$ & $\begin{array}{c}\text { Thermal } \\
\text { Conductivity }{ }^{\mathrm{b}} \\
\text { (mcal/cm-sec- }{ }^{\circ} \mathrm{C} \text { ) }\end{array}$ & $\begin{array}{l}\text { Geothermal } \\
\text { Gradient } \\
\left({ }^{\circ} \mathrm{C} / \mathrm{m}\right)\end{array}$ & $\begin{array}{c}\delta^{18} \mathrm{O} \\
\text { Temperature } \\
\text { of } \\
\text { Formation, }{ }^{\mathrm{c}} \\
T_{1} \\
\left({ }^{\circ} \mathrm{C}\right)\end{array}$ & $\begin{array}{c}\delta^{18} \mathrm{O} \\
\text { Temperature } \\
\text { of } \\
\text { Formation, }{ }^{\mathrm{d}} \\
T_{2} \\
\left({ }^{\circ} \mathrm{C}\right)\end{array}$ & $\begin{array}{l}\text { Temperature } \\
\text { Present at } \\
\text { Depth of Bed } \\
\left({ }^{\circ} \mathrm{C}\right)\end{array}$ & $\begin{array}{c}\text { Calculated } \\
\text { Temperature } \\
\text { of Formation } \mathrm{f} \\
\left({ }^{\circ} \mathrm{C}\right)\end{array}$ \\
\hline $463-6-6,36 \mathrm{~cm}$ & 46 & 45 & 1.24 & 2.14 & 0.058 & 23 & 10 & 4 & 4 \\
\hline $463-10-6,82 \mathrm{~cm}$ & 80 & 67 & 1.24 & 2.14 & 0.058 & 22 & 10 & 6 & 8 \\
\hline $463-22, \mathrm{CC}$ (A) & 195 & 73 & 1.24 & 2.14 & 0.058 & 33 & 20 & 13 & 14 \\
\hline $463-52, \mathrm{CC}$ & 461 & 103 & 1.24 & 2.14 & 0.058 & 56 & 42 & 28 & 37 \\
\hline $\begin{array}{l}\text { Base of sediment } \\
\text { section drilled }\end{array}$ & 820 & 117 & 1.24 & 2.14 & 0.058 & - & - & 49 & 49 \\
\hline $464-10-3,70 \mathrm{~cm}$ & 83 & 75 & 1.20 & $1.87 / 2.32$ & $0.064 / 0.052$ & 23 & 10 & $7 / 6$ & $4 / 3$ \\
\hline $464-10-4,34 \mathrm{~cm}$ (A) & 84 & 75 & 1.20 & $1.87 / 2.32$ & $0.064 / 0.052$ & 31 & 18 & $7 / 6$ & $4 / 3$ \\
\hline $464-11-1,41 \mathrm{~cm}$ & 89 & 95 & 1.20 & $1.87 / 2.32$ & $0.064 / 0.052$ & 34 & 21 & $7 / 6$ & $15 / 14$ \\
\hline $464-14-1,40 \mathrm{~cm}$ & 118 & 98 & 1.20 & $1.87 / 2.32$ & $0.064 / 0.052$ & 33 & 20 & $9 / 8$ & $17 / 16$ \\
\hline $464-17, \mathrm{CC}$ & 146 & 100 & 1.20 & $1.87 / 2.32$ & $0.064 / 0.052$ & 52 & 39 & $11 / 9$ & $19 / 18$ \\
\hline $\begin{array}{l}\text { Base of sediment } \\
\text { section drilled }\end{array}$ & 310 & 115 & 1.20 & $1.87 / 2.32$ & $0.064 / 0.052$ & - & - & $21 / 17$ & $29 / 26$ \\
\hline $465-2, C C(A)$ & 9 & 50 & 1.36 & 3.32 & $0.041^{8}$ & 20 & 8 & 2 & 5 \\
\hline $465-2, C C$ (B) & 9 & 50 & 1.36 & 3.32 & 0.041 & 19 & 7 & 2 & 5 \\
\hline $465 \mathrm{~A}-40-1,26 \mathrm{~cm}$ & 410 & 102 & 1.36 & 3.32 & 0.041 & 47 & 34 & 18 & 27 \\
\hline $\begin{array}{l}\text { Base of sediment } \\
\text { section drilled }\end{array}$ & 415 & 104 & 1.36 & 3.32 & 0.041 & - & - & 19 & 27 \\
\hline $466-9-1,64 \mathrm{~cm}$ & 75 & 40 & 1.36 & 3.32 & 0.041 & 30 & 17 & 4 & 4 \\
\hline $466-15-5,45 \mathrm{~cm}$ & 128 & 72 & 1.36 & 3.32 & 0.041 & 25 & 12 & 7 & 7 \\
\hline $466-27, \mathrm{CC}$ (A) & 236 & 87 & 1.36 & 3.32 & 0.041 & 21 & 9 & 11 & 18 \\
\hline $466-34-1,8 \mathrm{~cm}$ & 293 & 102 & 1.36 & 3.32 & 0.041 & 34 & 21 & 13 & 19 \\
\hline $\begin{array}{l}\text { Base of sediment } \\
\text { section drilled }\end{array}$ & 310 & 104 & 1.36 & 3.32 & 0.041 & - & - & 14 & 20 \\
\hline
\end{tabular}

a Site 463 based on average of 7 nearby heat-flow stations; Site 464 on 1 nearby station (see Fig. 1) from Jessop et al. (1976); Site 465 calculated from a beothermal gradient measured in situ; the Site 465 value is also used for Site 466 .

b Site 463 based on average of 8 nearby measurements from Jessop et al. (1976); Site 464 first value is average of 2 nearby measurements, second value is

from shipboard measurements during Leg 62, as is the value for Site 465; the measured value at Site 465 is also used for Site 466 .

c Calculated from Clayton et al. (1972).

d Calculated from Knauth and Epstein (1975).

${ }^{e}$ Based on geothermal gradients in fourth column and bottom-water temperatures of $1.5^{\circ} \mathrm{C}$

f 40 m.y. after deposition, using bottom paleotemperatures from Douglas and Savin (1973).

8 In situ measurement. 


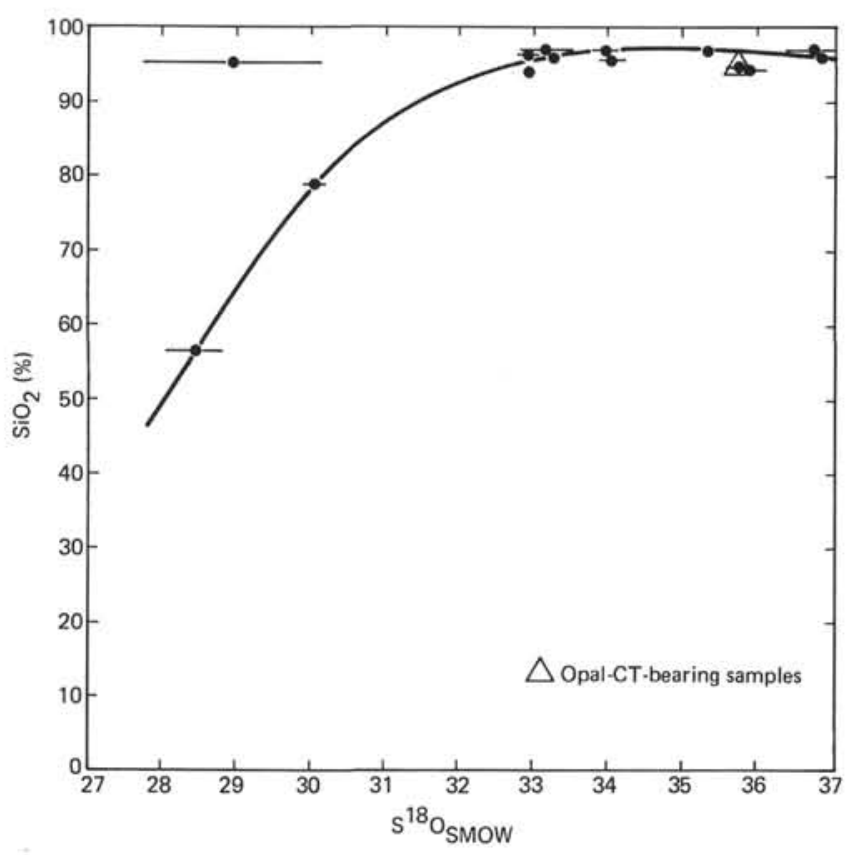

Figure 6. $\delta^{18} \mathrm{O}$ versus $\mathrm{SiO}_{2}$ content of Leg 62 cherts. Major and minor element compositions of Leg 62 cherts are presented by Hein et al. (this volume).

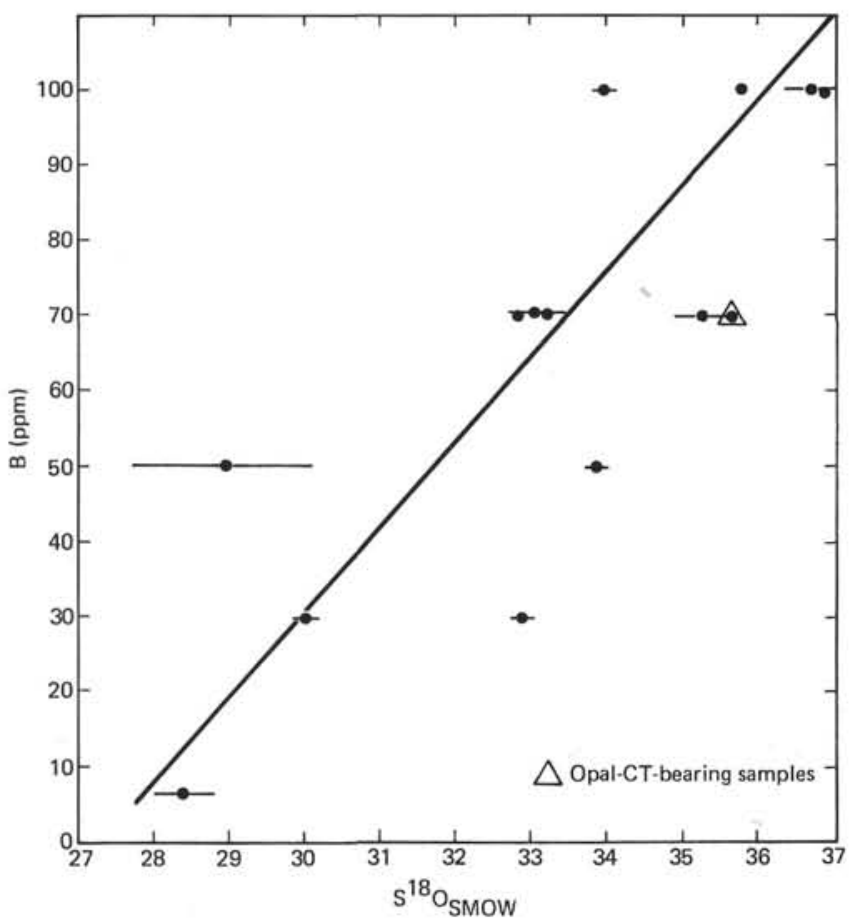

Figure $7 . \delta^{18} \mathrm{O}$ versus boron contents of Leg 62 cherts.

geothermal gradients would be $0.08,0.49,0.06$, and $0.05^{\circ} \mathrm{C} / \mathrm{m}$ for Sites $463,464,465$, and 466 , respectively. Except for Site 464, these geothermal gradients are similar to, but slightly greater than, the contemporary gradients of $0.06,0.06,0.04$, and $0.04^{\circ} \mathrm{C} / \mathrm{m}$ for the same sites, respectively. We do not know why there is such a

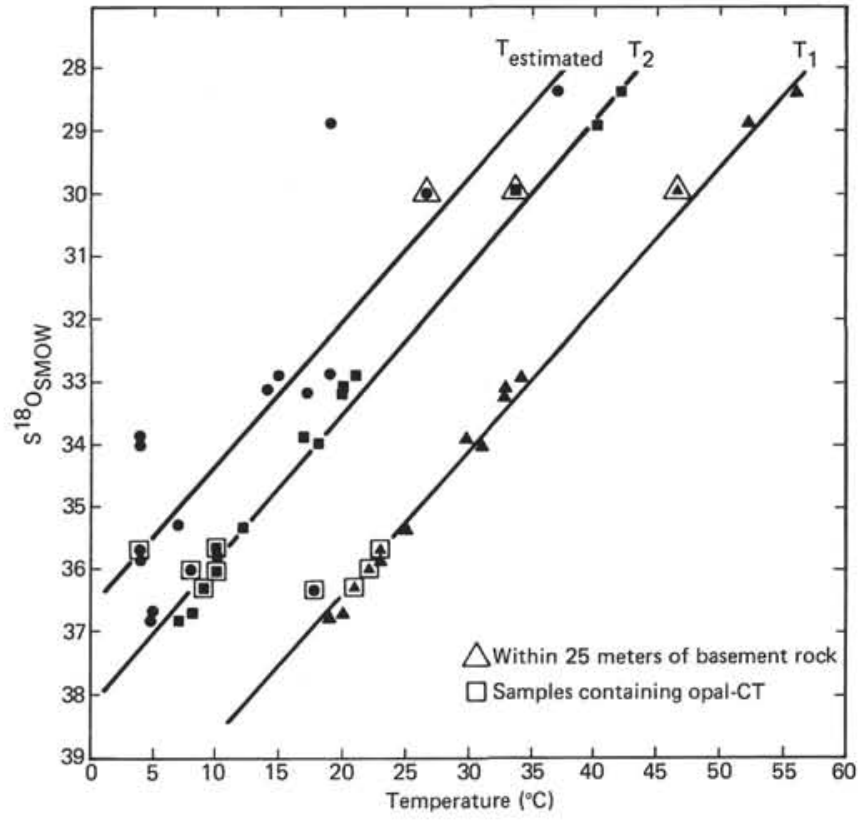

Figure $8 . \delta^{18} \mathrm{O}$ compositions versus possible temperatures of formation of Leg 62 cherts. $T_{1}$ represents temperatures derived from the silica/water fractionation factor of Clayton et al. (1972). $T_{2}$ represents temperatures derived from the equation of Knauth and Epstein (1976). $T_{\text {estimated }}$ represents estimated temperatures of formation for cherts, assuming the various paleoceanographic conditions outlined in the text and in Table 2.

large discrepancy for Site 464; a possibility is that we may have incorrectly assumed a constant geothermal gradient for both the pelagic clay and the carbonate sections (Fig. 2). However, possible errors related to this assumption are probably not great enough to account for the large discrepancy between the paleogeothermal and contemporary geothermal gradients at Site 464 . The location of Site 464 near the hot spot that created the adjacent Emperor Seamounts may have created a regime of higher temperatures at the site early in its history.

As suggested by Knauth and Epstein (1975), opalCT-rich rocks may reflect bottom-water temperatures more than do quartz cherts. The one sample we analyzed that contains abundant opal-CT supports their notion, and plots much closer to the Douglas and Savin (1973) bottom-water-temperature curve than do other samples of the same age (Fig. 9). However, Knauth and Epstein caution that temperatures derived from opalCT do not always agree with bottom-water temperatures obtained by other means.

\section{COMPARISONS WITH CONTINENTAL-MARGIN SILICEOUS ROCKS}

Hein et al. (1978) suggested that opal-A transforms into opal-CT faster and at higher temperatures in continental-margin deposits than in deep-sea, open-ocean deposits. Continental-margin deposits are characterized by high rates of sedimentation, and temperature is a dominant control in the transformation of silica, whereas in the open-ocean environment, where rates of 


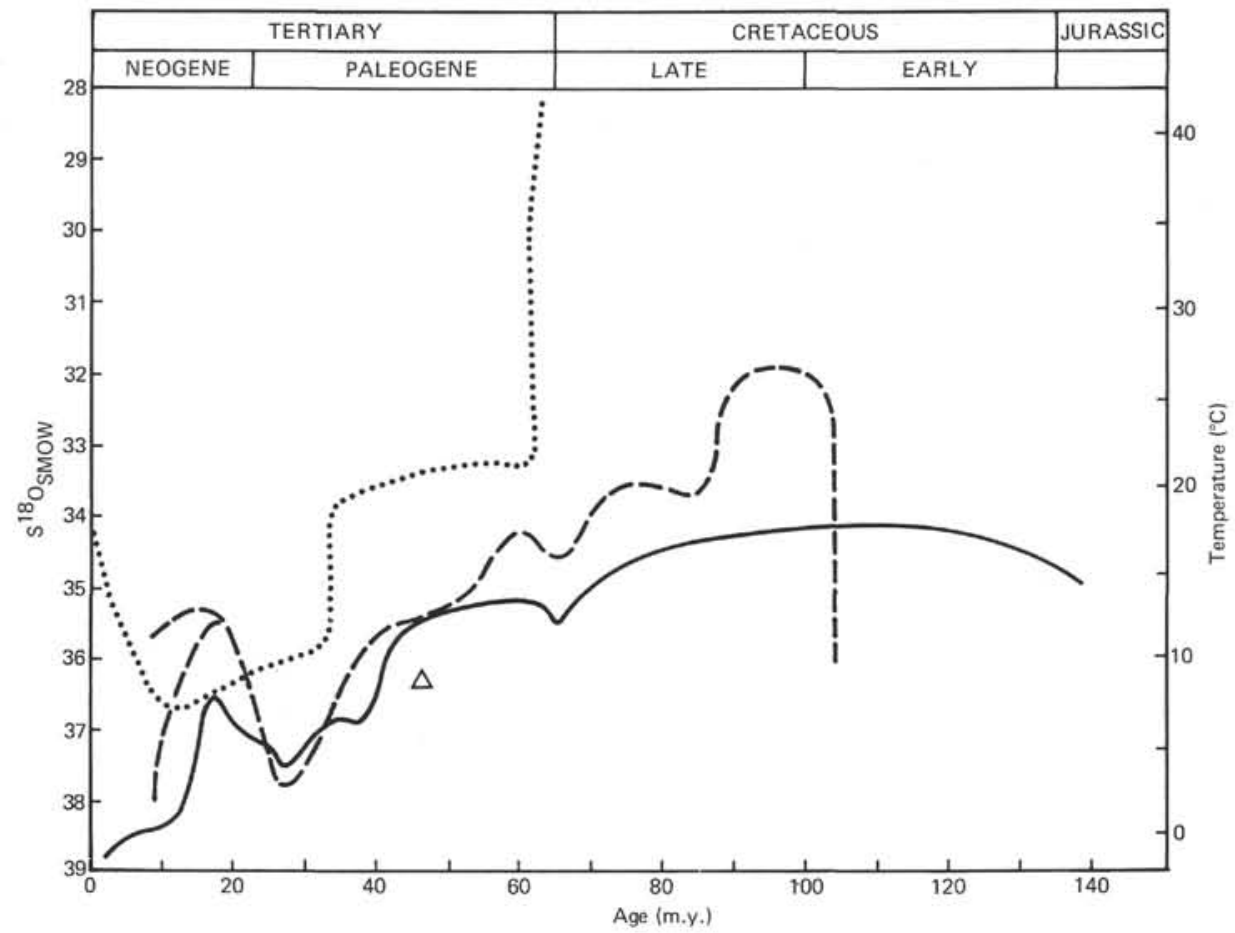

Figure 9. $\delta^{18} \mathrm{O}$ and temperature, using Knauth and Epstein's (1976) curve, versus age. The curve derived from our data (dotted) and that from the data of Kolodny and Epstein (1976; dashed) are translated $40 \mathrm{~m} . \mathrm{y}$. toward the present, because deep-sea cherts take about $40 \mathrm{~m} . \mathrm{y}$. after deposition of the host sediment to form. The solid line represents Douglas and Savin's (1973) bottom-water temperature curve derived from isotopic analysis of benthic foraminifers. The triangle represents the Leg 62 sample composed mainly of opal-CT.

sedimentation are generally very low, time plays an increasingly important role relative to temperature (see fig. 9 of Hein et al., 1978; Pisciotto, 1978). In both environments, the chemistry of the host sediments and pore waters also influence silica transformations (Kastner et al. 1977; Knauth, 1979).

The transformation from opal-CT to quartz and the maturation of quartz in open-ocean cherts likewise may occur slower and at lower temperatures than the same transformations in continental-margin deposits. This relationship can be illustrated by comparing values of $\delta^{18} \mathrm{O}$ versus quartz crystallinity of Leg 62 cherts with such values for siliceous rocks in the Monterey Formation of California (Fig. 5; Pisciotto, 1978); indeed, the curve for the Monterey Formation falls below (lighter $\delta^{18} \mathrm{O}$, greater temperatures) that of Leg 62 cherts, suggesting higher temperatures of formation. An alternative explanation for the offset of the curves in Figure 5 is that Pisciotto (1978) may have assumed incorrectly a $0.0 \%$ v value for the water in which the Monterey Formation siliceous deposits equilibrated.

\section{ACKNOWLEDGMENTS}

We appreciate technical and analytical help from Eva Vanek, Mary Ann Allan, Sara Monteith, and Dorothy Sicard, U.S. Geological Survey, and Crystal S. Lipton and Rita Pujalet, University of Hawaii. L. Paul Knauth, Arizona State University, and George W. Moore and T. L. Vallier, U. S. Geological Survey, provided critical reviews. H.-W. Yeh acknowledges NSF Grant OCE-78-25283. Hawaii Institute of Geophysics contribution number 1048. Research completed in con- junction with IGCP Project 115, Siliceous Deposits of the Pacific Region.

\section{REFERENCES}

Clayton, R. N., O'Neil, J. R., and Mayeda, T. K., 1972. Oxygen isotope exchange between quartz and water. J. Geophys. Res., 77: 3057-3067.

Craig, H., 1961. Standards for reporting concentrations of deuterium and oxygen-18 in natural waters. Science, 133:1833-1834.

Degens, E. T., and Epstein, S., 1962. Relation between $\mathrm{O}^{18} / \mathrm{O}^{16}$ ratios in coexisting carbonates, cherts, and diatomites. Bull. Am. Assoc. Petrol. Geol., 46:534-542.

Douglas, R. G., and Savin, S. M., 1973. Oxygen and carbon isotope analyses of Cretaceous and Tertiary foraminifera from the central North Pacific. In Winterer, E. L., Ewing, J. I., et al., Init. Repts. DSDP, 17: Washington (U.S. Govt. Printing Office), 591-605.

Hein, J. R., Scholl, D. W., Barron, et al., 1978. Diagenesis of late Cenozoic diatomaceous deposits and formation of the bottom simulating reflector in the southern Bering Sea. Sedimentology, 25:155-181.

Jessop, A. M., Hobart, M. A., and Sclater, J. G., 1976. The world heat flow data collection-1975. Energy, Mines and Resources Canada, Earth Physics Branch, Geothermal Service of Canada, 5.

Kastner, M., 1976. Diagenesis of basal sediments and basalts of Sites 322 and 323, Leg 35, Bellinghausen Abyssal Plain. In Hollister, C. D., Craddock, C., et al., Init. Repts. DSDP, 35: Washington (U.S. Govt. Printing Office), 513-528.

Kastner, M., Keene, J. B., and Gieskes, J. M., 1977. Diagenesis of siliceous oozes. I. Chemical controls on the rate of opal-A to opal-CT transformation-an experimental study. Geochim. Cosmochim. Acta, 41:1041-1059.

Knauth, L. P., 1979. A model for the origin of chert in limestone. Geology, 7:274-277. 
Knauth, L. P., and Epstein, S., 1975. Hydrogen and oxygen isotope ratios in silica from the Deep Sea Drilling Project. Earth Planet. Sci. Lett., 25:1-10.

, 1976. Hydrogen and oxygen isotope ratios in modular and bedded cherts. Geochim. Cosmochim. Acta, 40:1095-1108.

Kolodny, Y., and Epstein, S., 1976. Stable isotope geochemistry of deep sea cherts. Geochim. Cosmochim. Acta, 40:1195-1209.

Lawrence, J. R., Gieskes, J. M., and Broecker, W. S., 1975. Oxygen isotope and cation composition of DSDP pore waters and the alteration of layer II basalts. Earth Planet. Sci. Lett., 27:1-10.

Levitan, M. A., Dontsova, E. I., Lisitsyn, A. P., et al., 1975. The origin of chert in the sediments of the Pacific Ocean from data of oxygen isotopic analysis and a study of the distribution of chert. Geokhimiya, 3:420-430.
Murata, K. J., and Norman, M. B. II, 1976. An index of crystallinity for quartz. Am. J. Sci., 276:1120-1130.

Pisciotto, K. A., 1978. Basinal sedimentary facies and diagenetic aspects of the Monterey Shale, California [Ph.D. dissert.]. University of California, Santa Cruz.

Savin, S. M., 1977. The history of the earth's surface temperature during the past 100 million years. Ann. Rev. Earth Planet. Sci., $5: 319-355$.

Taylor, H. P. Jr., and Epstein, S., 1962. Relationship between $\mathrm{O}^{18}$ / $\mathrm{O}^{16}$ ratios in coexisting minerals of igneous and metamorphic rocks: I. Principles and experimental results. Geol. Soc. Am. Bull., 73:461-480. 